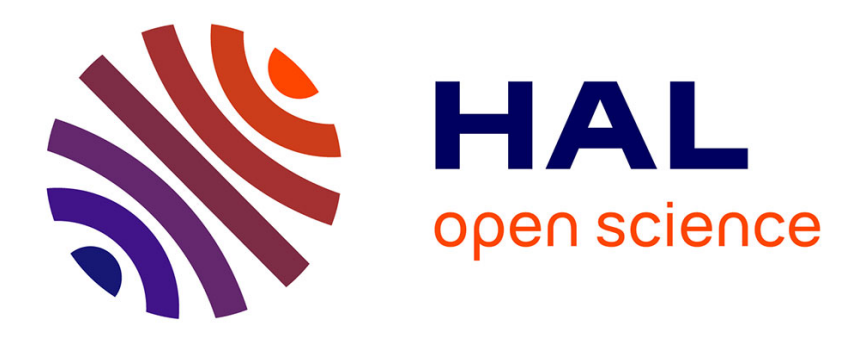

\title{
Female Overrepresentation in Public and Nonprofit Sector Jobs
}

\author{
Joseph Lanfranchi, Mathieu Narcy
}

\section{To cite this version:}

Joseph Lanfranchi, Mathieu Narcy. Female Overrepresentation in Public and Nonprofit Sector Jobs. Nonprofit and Voluntary Sector Quarterly, 2013, 44 (1), pp.47-74. 10.1177/0899764013502579 . halshs-01081038

\section{HAL Id: halshs-01081038 \\ https://shs.hal.science/halshs-01081038}

Submitted on 6 Nov 2014

HAL is a multi-disciplinary open access archive for the deposit and dissemination of scientific research documents, whether they are published or not. The documents may come from teaching and research institutions in France or abroad, or from public or private research centers.
L'archive ouverte pluridisciplinaire HAL, est destinée au dépôt et à la diffusion de documents scientifiques de niveau recherche, publiés ou non, émanant des établissements d'enseignement et de recherche français ou étrangers, des laboratoires publics ou privés. 


\section{Female overrepresentation in public and nonprofit sector jobs: Evidence from a French national survey}

\section{Joseph Lanfranchi}

Centre d'Etudes de l'Emploi and LEMMA, University Panthéon-Assas, Sorbonne Universités, Paris.

CEE - "Le Descartes I", 29 promenade Michel Simon, 93166 Noisy Le Grand, France. Tel: +33 (0)1 45926972 - Fax.: +33(0)1 49310244

Email: 1anfranchi@u-paris2.fr

Mathieu Narcy (corresponding author)

Centre d'Etudes de l'Emploi and Erudite, University of Paris-Est Créteil.

CEE - "Le Descartes I", 29 promenade Michel Simon, 93166 Noisy Le Grand, France.

Tel: +33 (0)1 45926958 - Fax.: +33(0)1 49310244

Email: mathieu.narcy@cee-recherche.fr

\section{Keywords}

Public and nonprofit sectors, overrepresentation of women, occupational segregation, familyfriendly policies 


\begin{abstract}
Women are overrepresented in the public and nonprofit sectors. This article aims to bring to light the reasons behind this phenomenon. The originality of the employer-employee matched data used allows us to consider a large scope of potential reasons. Using a non-linear decomposition technique (Fairlie, 2005), we find that in addition to the well-known occupational segregation effect, the overrepresentation of women in the public and nonprofit sectors is associated with two common factors: greater offerings of family-friendly practices and higher attraction of men for certain fringe benefits that are more frequently provided by the for-profit sector. Sector-specific factors also exist. The higher wage advantage obtained by women compared with men working in the public sector rather than in the for-profit sector contributes to the feminization of the public sector. Similarly, the overrepresentation of women in the nonprofit sector is linked to greater access to part-time jobs and shorter workweeks there.
\end{abstract}




\section{Introduction}

It is well known that women are overrepresented in the public and nonprofit sectors and represent a lower share of the for-profit sector workforce. In France, according to the Annual Report on the Civil Service, $59.8 \%$ of jobs in the public sector were held by women in 2010, and a survey of French nonprofit organizations conducted by $\mathrm{CNRS}^{1}$ reported that women represented 70\% of their paid labor force in 2005 (Tchernonog, 2007). By comparison, the percentage of women in the French for-profit sector was approximately $39 \%$. The statistical evidence for the United States is similar: according to data from the 2010 Current Population Survey, $56.5 \%$ of the employed labor force in the government sector is female, compared with only $44 \%$ in the for-profit sector, whereas in the nonprofit sector, the proportion of women is approximately 68\% (Light, 2002). Finally, in most OECD countries, the LABORSTA database, which is operated by the International Labor Organization, shows that more than half of public sector workers are women. International statistical figures for the workforce in the nonprofit sector are more difficult to find, but Anheier (2005) reports that the share of female employment in nonprofit organizations is greater than the proportion of female employees in other private industries.

The aim of this article is to identify the reasons for this overrepresentation of women in the public and nonprofit sectors. Assuming that the observed gender differences in sectoral employment are generated by a matching between organizations that are characterized by different goals and practices and workers whose preferences differ according to gender, we investigate the influence of the following types of determinants. In particular, we focus on the practices chosen by employers: the compensation package including both wage levels and pecuniary fringe benefits, and the set of family-friendly policies. We also explore how female and male employees' tastes can differ in terms of the intrinsic and extrinsic characteristics of 
jobs. Finally, as public and nonprofit organizations operate frequently in sectors like education, health and social care, they tend to offer female-dominated occupations. Hence, we consider the influence of the occupational segregation effect on the high representation of women in the public and nonprofit sectors.

The question of the overrepresentation of women in the public and nonprofit sectors has rarely been addressed in the literature. A notable exception is the study by Preston (1990), who examines the reasons that explain why women choose white-collar jobs in either the forprofit or nonprofit sectors in the United States. The high representation of women in the nonprofit sector primarily results from an occupational segregation effect and differing compensation structures. However, this study was unable to measure the relative contributions from gender differences in the set of factors that explain the sector choice. To address this drawback, we perform the non-linear decomposition technique proposed by Fairlie (2005). Extending the analysis to the case of the nonprofit, for-profit and public sectors, we decompose the gender gap in terms of the probability of belonging to one of these sectors rather than to one of the remaining two. In contrast with previous literature, this technique allows us to determine not only which factor is relevant for explaining the gender gap in sectoral employment but, most importantly, how much the factor contributes to explaining this gap. Apart from this methodological interest, the results may also offer recommendations in terms of active labor market policy to promote equal opportunities for access to all sectors of employment. To emphasize this point, if the proportional share of employment between male and female workers in all sectors is regarded as an equity norm, stated as a societal goal, then the use of this type of decomposition will help to shape the optimal policies that can be used to obtain a more equitable gender distribution of employment. 
Our empirical analysis is based on a French employer-employee matched data set from the Families and Employers survey conducted by INED and INSEE $^{2}$ in 2004-2005. We are not aware of another national database in which employees provide information on their personal and job characteristics while employers provide details on their practices in the fields of pay, non-monetary advantages and family-friendly policies. Consequently, previous studies have been unable to investigate the relative weights of all these factors in explaining the gender differences in employment by sector.

This paper is organized as follows. In the next section, we review the theoretical explanations for the gender distribution in the public, for-profit and nonprofit sectors. Section 3 describes the data that are used. In sections 4 and 5, we empirically investigate the employee and sector match and then assess which of these determinants differs significantly between male and female employees. In the sixth section, we present the decomposition methodology. The results in terms of the relative weight of these determinants in the gender differences in sectoral employment are interpreted in the seventh section. The final section concludes the paper. 


\section{Theoretical explanations of the gender distribution in the public, for-profit and nonprofit sectors}

From a theoretical perspective, the observed gender differences in sectoral employment are the result of a combination of demand- and supply-side factors as well as occupational segregation by gender. First, the demand-side factors reflect differences in the nature of the goods and services produced, goals and constraints of organizations. For example, because nonprofit and public organizations do not seek profit maximization, the constraints on their pay-setting practices derive from the scrutiny of donors and citizens. Because these organizations are usually unable to offer wages that are as high as their for-profit counterparts, they may compensate their employees through more generous fringe benefits and familyfriendly policies. Moreover, nonprofit and public organizations provide public goods and services that generate social benefits. Consequently, these organizations may adopt a compensation structure that attracts workers who are motivated by participating in socially desirable activities rather than by money. Second, on the supply side, each worker compares the monetary plus non-monetary benefits offered by each sector and prioritizes a job in the sector that provides him or her with the highest utility. This choice is shaped not only by worker preferences but also by the constraints under which they make their choices. Female and male workers may have different preferences regarding their employment sector choices, and they do not confront the same constraints. For example, males and females may differ in their motivation to participate in the production of goods with social benefits. Moreover, employment sector choices are made within the context of social norms that govern the division of domestic tasks and may thus induce women to seek jobs with family-friendly practices. Finally, a competitive view of the labor market neglects the structural factors that interfere with the relative desirability of sectoral employment. Among these factors, an 
occupational segregation effect can explain the high representation of women in the public and nonprofit sectors. For example, the education, health and social care sectors, the favored domains of action among public and nonprofit organizations, offer female-dominated occupations (e.g., teaching, nursing, personal services). Hence, the observed gender distribution across sectors is the result of a matching between sectors that are distinguished by different objectives and practices and workers whose preferences differ according to gender.

In the following, we review relevant empirical studies that confirm the role of compensation structures, family-friendly policies, the nature of goods and services produced, and individual preferences in explaining the observed gender gap in sectoral employment.

Some studies find that the wage gain obtained by women from working in the public sector rather than the for-profit sector is higher than that obtained by men. This result may be partly explained by the lower wage losses incurred by mothers in the public sector as a result of career interruptions to have children and care for them compared with mothers in the forprofit sector. For example, Nielsen et al. (2004) find a child premium in the Danish public sector and a child penalty in the for-profit sector. Moreover, the authors show that this advantage provided by the public sector leads women who are planning to have children to prefer jobs in that sector. In France, women join the public sector more frequently because, as Meurs and Ponthieux (2006) suggest, their wage advantage from working in the public sector rather than in the for-profit sector is higher than that obtained by men. The same result has also been observed in the United States (Hoffnar and Greene, 1998).

Concerning the wage differential between the nonprofit and for-profit sectors, the study by Preston (1990) reveals that white-collar workers in the nonprofit sector earn lower wages than those in the for-profit sector. However, this wage disadvantage is only half as high for women as it is for men and thus may constitute a significant explanation for the overrepresentation of women in nonprofits. 
One of the reasons for the relative wage advantage of women in the public and nonprofit sectors is that they are treated more equally in these sectors than in the for-profit sector. Although there are no studies of wage discrimination in the public sector in France, the gender wage ratio in 2005 was $84 \%$ in the public sector compared with $77 \%$ in the for-profit sector (INSEE, 2007). This difference in treatment between the two sectors is partly explained by the different distribution of qualifications between genders and by the finding that the career paths of men and women are more similar in the public sector than in the for-profit sector in France. Several studies confirm that the nonprofit sector also appears to treat women more equally than the for-profit sector does. In France, Etienne and Narcy (2010) use a quantile regression technique to show that female employees in nonprofits suffer less wage discrimination than those in the for-profit sector, all along the wage distribution. The study by Leete (2000) in the United States presents similar conclusions regarding the gender differences in average wages. However, the magnitude of the gender pay gap in the nonprofit sector varies significantly across industries. In fact, Faulk et al. (2012) find a greater gender pay equity in industries with a higher proportion of female-dominated occupations and with a higher percentage of nonprofit employees.

Ponthieux and Schreiber (2006) show that the sharing of domestic chores in French couples is very slow to evolve; women devote twice as much time to housework as men do. Likewise, the time spent caring for children remains largely monopolized by women. Under these conditions, if there are substantial differences in the family-friendly practices of employers, then women may well be attracted to those sectors of the labor market offering the best opportunities for reconciling family and professional life. The differences in the familyfriendly practices of employers among the nonprofit, for-profit and public sectors have rarely been addressed in the literature ${ }^{3}$. The originality of the database that is used in this paper 
allows us to fill this gap by providing a detailed analysis of these differences. In addition to the differences in family-friendly practices, these sectors may differ in their organization of working time and hence in their offers of opportunities to reconcile family and professional life. For example, the particularly frequent offerings of part-time work in the public and nonprofit sectors may appear to be a possible means of adapting to the demands of family life. Thus, Bué (2002) shows that $34 \%$ of women who work part time do so to be able to care for their children, compared with only $6 \%$ of men. Lanfranchi and Narcy (2010) show that the optimal number of working hours is lower for nonprofit workers than for for-profit workers.

For some workers, in addition to extrinsic rewards, the social cause pursued by an organization may represent a motive to seek a job in the organization. Public and nonprofit organizations are perceived to produce goods and services that naturally generate more social benefits than for-profit firms. In fact, public and nonprofit organizations often dominate the human and social services in developed economies, as they are more present than for-profit organizations in fields such as health, social services and education. Consequently, these employers will be able to attract workers with a high degree of pro-social motivation. Prosocial motivation refers to workers' preferences that result in pro-social behavior, which is defined as actions that directly benefit other people or society as a whole. If pro-social behavior does not stem from pecuniary or other material rewards or from the desire to develop a valuable reputation, then pro-social motivation is considered a specific form of intrinsic motivation $^{4}$ (Benabou and Tirole, 2006). The job design literature considers opportunities to benefit others as intrinsic rewards (see, for example, Hackman and Oldham, 1975). Consequently, we hypothesize that nonprofit and public workers are more intrinsically motivated than their for-profit counterparts with respect to their jobs. 
Several empirical studies provide evidence of differences in the self-reported motivations of workers across sectors and a greater prevalence of intrinsic motivations among nonprofit and public workers. For example, Borzaga and Tortia (2006) examine the motives that induce workers to choose a particular organization by exploiting a unique set of data on the Italian social services sector. The authors distinguish among public, for-profit and nonprofit organizations ${ }^{5}$. The results show that public and nonprofit workers are significantly more likely than for-profit workers to have chosen an organization because they are attracted by their interest in the sector. Moreover, nonprofit workers attach more importance to workforce involvement and to the manner in which an organization works with its service users. Other studies also confirm higher levels of pro-social behavior among public and nonprofit workers. In the specific labor market context, pro-social behavior is exhibited by donated labor, referring to additional effort beyond what is contractually necessary. Gregg et al. (2011) find that donated labor, measured by unpaid overtime, is higher in the UK public and nonprofit sectors than in the for-profit sector. Similarly, Lanfranchi and Narcy (2006) find that employees in the French nonprofit sector accept a lower wage than they could obtain in the for-profit sector while exerting at least the same amount of effort. Using data on the Italian social services sector, Mosca et al. (2007) show that nonprofit organizations attract workers with higher levels of intrinsic motivation by paying low wages that are compensated by high levels of non-pecuniary compensation resulting from the provision of relational goods.

From this perspective, we must investigate the possibility that women are more likely to display social preferences. Psychological studies of female specificities suggest that women demonstrate a more strongly developed ethos of care and attention to others in their mode of expression (Gilligan, 1982). In her research on female characteristics, Bem (1974) also reports that sensitivity to the needs of others is a primary trait. However, economic experiments pertaining to social preferences have failed to identify systematic differences between the 
genders, except that female behavior appears to be more consistent with the norm in environments where attention to others is naturally appropriate (Croson and Gneezy, 2009) and that they are more socially oriented only when decisions do not involve a risk component (Eckel and Grossman, 2008).

However, the model of the free choice of employment sector is limited by constraints, such as the occupational segregation from which working women may suffer. In France, the Ministry of Labor lists 84 occupational categories, ten of which contain more than half of all female employees. Some of the most "female" occupations are more frequent in the public and nonprofit sectors, including teachers, nursery assistants and low-level administrative employees in civil service. 


\section{Data}

The data used are obtained from the Families and Employers survey conducted by INED and INSEE in 2004-2005. The empirical analysis in this article is based on the employeeemployer matched data file from the survey. This database is unique in that it contains detailed information on both the characteristics of employees and the human resources practices of their employers.

In the "individual" section of this matched file, 9,547 men and women between the ages of 20 and 49 participated in face-to-face interviews. This section provides details regarding the socio-demographic characteristics of these individuals, their employment situations, their job characteristics and their perceptions of the relationship between family life and professional life.

The "employers" section is based on a mail survey sent to the human resources manager of the establishments. This survey covers only establishments with 20 or more employees that employ the people who are interviewed in the "individual" section of the survey. A total of 2,673 establishments were surveyed; these establishments belong to every branch of activity in the for-profit, public and nonprofit sectors. The use of matched data provides more reliable information regarding the legal status of the organizations, as this information is provided by the employers. Employer characteristics include questions regarding work organization, working environment and, central to this study, both family-friendly measures and fringe benefits offered. We identify four main groups of family-friendly measures: the choice of working hours and working times in relation to family situations, the adoption of various child-care systems, the distribution of family-related fringe benefits and adjustment of the legal reduction of working time ${ }^{6}$ in relation to an employee's family needs. Moreover, the survey identifies further fringe benefits that are not intended to reconcile family and 
professional life, such as holiday vouchers, life insurance policies, savings and pension plans, and mutual insurance schemes.

The matched data file that is used in this study contains 3,050 observations. Once the missing and aberrant observations are eliminated, our sample covers 2,721 employees, of whom 1,515 work in the for-profit sector, 962 in the public sector ${ }^{7}$ and 243 in the nonprofit sector. In our working sample, $44 \%$ of all employees are women. The proportion of women is higher in the nonprofit and public sectors than in the for-profit sector: $77 \%$ of nonprofit employees and $55 \%$ of public employees are female, compared with $40 \%$ in the for-profit sector. 


\section{Identification of the determinants of employee and sector match}

In this section, we identify the determinants of the relative probability of working in each of the three sectors. Three logit regression models are estimated for the probability of belonging to one of the three sectors studied rather than the other two sectors. Table 1 reports the estimates of the marginal effects.

\section{[Table 1 Here]}

After we control for employee and employer characteristics, gender remains a major determinant of the sector of work. In fact, our results show that controlling for a large set of determinants does not fully explain gender differences in the rate of participation in the nonprofit sector. However, if these determinants were actually equally distributed between male and female employees, then the former would be more likely than the latter to join the public sector. We also find that older employees are more likely to work in the public and nonprofit sectors than in the for-profit sector. In addition, employees with general lower secondary education are more likely to work in the for-profit sector than in the public sector.

According to standard economic theory, if employees expected higher pecuniary compensation in a given sector, then they would be more likely to join this sector. Therefore, we include in the logit regressions the estimated wage differentials among the nonprofit, public and for-profit sectors. These differentials were obtained with the assistance of estimated wage equations according to gender and sector ${ }^{8}$. The wage differential estimates reveal that the employees in the public sector have average hourly wages $4.9 \%$ and $4.4 \%$ higher than those in the for-profit and nonprofit sectors, respectively. Comparing wages between the nonprofit and for-profit sectors, we find that employees enjoy only a very slight 
gain $(+1.0 \%)$ from joining the for-profit sector. Our estimated results show that only the predicted wage differential between the public and for-profit sectors had a positive effect on the choice of the former.

The characteristics of labor contracts vary significantly among sectors. Employees in parttime arrangements are more likely to work in the nonprofit sector, whereas the length of the workweek is significantly shorter in the public and nonprofit sectors than in the for-profit sector. Consequently, the nonprofit and public sectors can attract employees who strongly value non-work activities and particularly employees wishing to reconcile family and professional life. We also find that night work is more common in public organizations than in nonprofits because of the high number of public hospitals and the inclusion of large public companies. Finally, shift work is significantly more frequent in the for-profit sector than in the public sector.

In the case of reduced working time, we consider whether the employer offers more days off than the legal minimum required number of 13 days granted and whether employees are permitted to regularly take these days off on the same day of the week, allowing parents to care for children on Wednesdays, for example ${ }^{9}$, or adding these days to ordinary holidays. On the first point, the nonprofit and public sectors employers appear significantly more generous than for-profit employers. Furthermore, nonprofit employees are also more likely to have the right to extend their holidays at will than their public counterparts.

Opportunities for adjusting working hours to reconcile family and professional life are significant determinants of the probability of working for the public sector rather than for the for-profit sector, but such opportunities do not affect the differences in the rate of employment between the nonprofit and for-profit sectors. Public organizations are significantly more likely than for-profit and nonprofit organizations to consider family life when implementing parttime arrangements and to offer the possibility of working from home in cases of personal 
constraints. Consistently granting part-time schedules to employees on request and adjusting working hours for the beginning of the school year are also practices that are implemented significantly more frequently in the public sector than in the for-profit sector. The reverse is observed concerning the possibility of considering family life when organizing campaigns and business travel. Regarding child care, both the provision of a day-care center and the possibility of access to holiday camps are significantly more common in the public sector. Furthermore, nonprofits are less likely than any other type of organization to offer a day nursery or access to holiday camps. With regard to family-related fringe benefits, the public sector again appears to be significantly more generous, especially in terms of financial aid for child care and in the allowances provided for children with disabilities. In summary, employees' access to family-friendly policies largely determines their match with the three sectors that are considered here. Therefore, as the conciliation between work and family remains an important problem for female employees in the context of the role differentiation within households, we expect these policies to play a major role in gender differences related to sector choice.

The offer of other types of fringe benefits may also influence the match between workers and sectors. We identify five such measures: holiday vouchers, life insurance policies, savings plans, pension plans and mutual insurance schemes. Unlike family-friendly measures, forprofit establishments offer more of these fringe benefits than the other two sectors, with the exception of holiday vouchers, which are more popular in the public and nonprofit sectors.

In the previous section, we noted that pro-social motivation is often offered as an explanation for sector choice. To the best of our knowledge, employees' pro-social motivation can best be measured with the following question: "How personally important do you think it is to have a job that allows you to help other people?" Unfortunately, this question is asked only in the International Social Survey Programme (ISSP) Work Orientations module. 
Nevertheless, the data from the Families and Employers survey allow us to consider several proxies of the pro-social and intrinsic motivations of employees.

First, we select two variables that we interpret as evidence of altruistic acts outside of a person's main job. In fact, pro-social values that attract individuals to the public and nonprofit sectors may also lead them to engage in other pro-social behaviors beyond the workplace, particularly volunteer involvement (Ertas, 2012). Hence, the first variable is involvement in an unpaid activity relating to campaigning or community interests, such as participating in a town council. Moreover, because religiosity increases volunteer involvement (Forbes and Zampelli, 2012), we consider a second binary variable that equals one if a respondent considers religion to be highly important in his or her daily life. These two variables are more likely to be observed in the nonprofit sector and, to a lesser degree, in the public sector than in the for-profit sector. However, the effects of these variables on sector choice are not significant at the usual statistical levels.

Second, because we hypothesize that pro-social motivated employees primarily care about intrinsic aspects of their jobs, we also consider two proxies for the intrinsic/extrinsic motivation of employees. Following a number of studies (see, for example, Borzaga and Tortia, 2006), our proxies are related to individuals' self-reported motivation with respect to their employment. In our survey, the respondents are asked to indicate their primary criterion of employment if they were seeking a job among a set of items. The best proxy for intrinsic motivation would have been the criterion "doing an important job," but in contrast to some surveys, such as The World Values Survey, this criterion is missing among the proposed list. Nevertheless, an available criterion can be considered a proxy for extrinsic motivation. This criterion records whether an individual declares the wage level to be the first criterion when seeking a new job. The results reveal that employees in the public sector are less likely to consider wage as a priority in their choice than their for-profit counterparts. Our second 
criterion is assumed to be a proxy for intrinsic motivation, as it records whether an individual declares that the choice of job should primarily be made to match one's tastes and/or training. The results show a positive and significant effect of this latter criterion on the likelihood of working in the nonprofit sector rather than in the for-profit sector.

Nevertheless, choosing a job to match one's tastes and/or training may also capture the reluctance to accept a job for which the employee would be overeducated. Obviously, this risk increases with the education level of the respondents. However, because education level is an explanatory variable of sector choice, our reported results cannot be explained by the tendency of nonprofit employees to be more educated than for-profit employees ${ }^{10}$.

Finally, the results obtained from the introduction of occupational dummies in the logit model reflect a high degree of segregation between sectors, with similarities between the public and nonprofit sectors. Thus, professors, scientists, teachers, and individuals in health and care occupations are found significantly more frequently in the public and nonprofit sectors. By contrast, the most commonly found occupations in the for-profit sector are engineers, executives, supervisors, technicians and skilled blue-collar workers. Finally, unskilled blue-collar workers, supervisors and technicians are the types of occupations that are less likely to be present in the public sector. 


\section{Gender differences in individual, job and employer characteristics}

The aim of this section is to analyze whether female and male employees differ in the key determinants of the distribution of employment by sector. Such differences will contribute to explain the overrepresentation of female employees in the nonprofit and public sectors. Table 2 below reports how individual, job and employer characteristics are distributed between male and female employees.

[Table 2 Here]

Among the individual characteristics that significantly influence the sector of work, we note that the average age is similar between genders but that women tend to be more educated than men.

Estimation of the wage gaps between sectors shows that by working in the public sector, women would earn an hourly wage that is $7.8 \%$ higher on average than the wage they could expect to earn in the for-profit sector, whereas this advantage is only $2.2 \%$ for men. This wage advantage, in addition to the effect of the wage differential on the probability of working for the public sector rather than in the for-profit sector, may explain the overrepresentation of female employees in the public sector. Female employees would have obtained a slight supplementary wage benefit of $1.4 \%$ from joining the nonprofit sector rather than the forprofit sector, whereas male employees would have obtained a wage penalty of $3.0 \%$. Finally, male and female employees can expect similar wage gains (approximately 4.4\%) when choosing the public sector rather than the nonprofit sector.

Relative to their job characteristics, male and female employees have different working hours. On average, women supply shorter weekly working hours and are significantly more 
likely to work part-time jobs compared with men. Furthermore, compared with male employees, female employees are also less likely to work weekends, nights or rotating shifts.

Compared with male employees, female employees more frequently work for organizations that allow their workforce to benefit from more than 13 days of reduced working time in the case of exceeding the statutory workweek. Access to such additional days off may be a benefit sought by women who are able to extend the legal period of their vacation to match their children's school holidays. This advantage, which is commonly offered by public and nonprofit organizations, is likely to explain differences in the representation of men and women in these sectors.

In terms of family-friendly practices, women are significantly overrepresented in workplaces in which part-time work is granted on request and in which family life is considered a determining factor of the length and adjustment of working hours. The findings also hold for workplaces in which employers have implemented policies that are designed to provide financial or other assistance for child care. The percentage of female employees in organizations that provide access to a day-care center is more than twice the percentage of male employees in such organizations. In addition, female employees are significantly more likely to receive financial assistance for child care or children with disabilities. Given the evidence that the birth of a child worsens the unequal sharing of domestic work within households and affects career opportunities for female employees, it would not be surprising that women predominantly choose to work in more family-friendly organizations in the public and nonprofit sectors.

When considering fringe benefits that are not related to family-friendly policies, our results illustrate that male employees enjoy significantly better access to specific savings plans, life insurance policies and funding of mutual insurance schemes compared to female employees. These facts are consistent with the findings of Bollinger and Hofstede (1987), 
who show that the "ideal job" for men requires access to a wide range of compensation schemes, unlike the "ideal job" for women. Therefore, if women attach less importance to some of these fringe benefits that are significantly more common in for-profit firms, then this could contribute to their overrepresentation in the public and nonprofit sectors.

Given the variables that are assumed to reflect the intrinsic/extrinsic motivation of employees, women are more likely than men to choose jobs that match their tastes and/or training, although their economic motivations are weaker. These results suggest that women are more likely than men to choose a job for intrinsic reasons.

Considering the proxies of employees' pro-social motivation, we find that men are less likely than women to declare that religion is important in everyday life but are more likely to engage in community interest activities. However, as participation in community interest activities may be constrained by time, this latter gender difference could be explained by the tendency of women to spend more time on domestic work and family care than men. Nevertheless, when we calculate gender differences in community interest activities conditional on individual characteristics (particularly, marital status and the number of children), the number and type of hours worked, and family-friendly practices, men remain more likely to participate in such activities than women ${ }^{11}$. Hence this difference does not appear to be explained by the greater time availability among men.

Finally, we observe a significantly different proportion of male and female employees in all of the eight occupational groups considered. As we observed in the section above, there are also significantly higher proportions of female-dominated occupations in the public and nonprofit sectors than in the for-profit sector. We find these higher proportions for clerks, service workers and certain professional occupations, such as health and social work professionals. Conversely, male-dominated occupations, such as skilled workers, technicians, foremen/women and supervisors, are less common in these sectors. Thus, the feminization of 
the public and nonprofit sectors is likely to reflect the pronounced feminization of certain occupations. 


\section{Methodology of non-linear decomposition}

In the two preceding sections, we have shown that female employees differ from male employees for many individual, job and employer characteristics and that many of these characteristics are important determinants of the sector of work. However, at this stage of the analysis, it is impossible to evaluate the magnitude of the contribution of each characteristic to the observed gender gap in employment sector probabilities.

To address this issue, we employ the non-linear decomposition method proposed by Fairlie (2005) to extend the well-known Oaxaca-Blinder technique to the binary case.

The difference in the mean probabilities $\bar{I}^{j}$ of being in sector $k$ rather than sector $l$ between female $(j=F)$ and male employees $(j=M)$ may be expressed as follows:

$$
\bar{I}^{F}-\bar{I}^{M}=\left[\sum_{i=1}^{N^{F}} \frac{F\left(X_{i}^{F} \hat{\beta}^{F}\right)}{N^{F}}-\sum_{i=1}^{N^{M}} \frac{F\left(X_{i}^{M} \hat{\beta}^{F}\right)}{N^{M}}\right]+\left[\sum_{i=1}^{N^{M}} \frac{F\left(X_{i}^{M} \hat{\beta}^{F}\right)}{N^{M}}-\sum_{i=1}^{N^{M}} \frac{F\left(X_{i}^{M} \hat{\beta}^{M}\right)}{N^{M}}\right]
$$

where $X_{i}^{j}$ is a raw vector of individual, job and employer characteristics for worker $i$ of gender $j . \hat{\beta}^{j}$ is the corresponding vector of coefficient estimates for gender $j . F($.$) is the$ cumulative distribution function from the logistic distribution, and $N^{j}$ denotes the sample size of group $j$. The first term in brackets represents the portion of the gender gap resulting from gender differences in the distribution of $X$ (the "explained" component). The second term in brackets shows the part that results from differences in the gender processes determining the level of $I$ (the "unexplained" component).

In equation (1), the female coefficients estimated $\left(\hat{\beta}^{F}\right)$ are used as weights for the first component, and the male distribution of the independent variables $\left(X^{M}\right)$ are used as weights for the second component. However, the literature has proposed different weighting schemes providing different estimates. We adopt the weighting method proposed by Oaxaca and 
Ransom (1994) that uses coefficients estimated from a logit regression on a pooled sample of female and male employees to weight the explained part of the decomposition expression.

In addition to the total contribution of all independent variables to the gender gap in the mean probabilities of being in one sector rather than another, the contributions of single independent variables (or groups of variables) are of interest for analysis purposes. However, identifying the contribution of each independent variable (or group of variables) to the gender gap requires an additional calculation. To simplify, we assume that we have two samples of equal size $N=N^{F}=N^{M}$ and that the vector $X$ includes only two variables, $X_{1}$ and $X_{2}$. Using coefficient estimates from a logit regression for a pooled sample $\hat{\beta}^{*}$, we can express the contribution of $X_{1}$ to the gender gap as follows:

$$
\frac{1}{N^{M}} \sum_{i=1}^{N^{M}}\left[F\left(\hat{\beta}_{0}^{*}+X_{1 i}^{F} \hat{\beta}_{1}^{*}+X_{2 i}^{F} \hat{\beta}_{2}^{*}\right)-F\left(\hat{\beta}_{0}^{*}+X_{1 i}^{M} \hat{\beta}_{1}^{*}+X_{2 i}^{F} \hat{\beta}_{2}^{*}\right)\right]
$$

Similarly, the contribution of $X_{2}$ is given by the following:

$$
\frac{1}{N^{M}} \sum_{i=1}^{N^{M}}\left[F\left(\hat{\beta}_{0}^{*}+X_{1 i}^{M} \hat{\beta}_{1}^{*}+X_{2 i}^{F} \hat{\beta}_{2}^{*}\right)-F\left(\hat{\beta}_{0}^{*}+X_{1 i}^{M} \hat{\beta}_{1}^{*}+X_{2 i}^{M} \hat{\beta}_{2}^{*}\right)\right]
$$

Hence, the contribution of each variable to the gender gap is equal to the average predicted probability from replacing the male distribution with the female distribution of that variable while holding the distribution of the other variables constant ${ }^{12}$. In sum, the contributions of each independent variable must be equal to the total contribution of the entire set of independent variables.

The estimation procedure of the relative contribution of each variable consists of several technical steps that are presented in detail in the seminal work of Fairlie (2005). 


\section{The reasons for the gender differences in sectoral employment}

Table 3 presents the results of the decomposition of gender differences in the probabilities of working in one sector rather than another.

\section{[Table 3 Here]}

At the top of Table 3, we can observe that the observed gender gap is higher when we consider the nonprofit/for-profit comparison (18 percentage points). Focusing on the two other comparisons, we find that the gender gap in sector employment probability is approximately 14 percentage points. More interestingly, the gender differences in all of the included individual, job and employer characteristics explain a large share of the observed gender gap in employment sector choices (the "explained" component). More than $100 \%$ of the gender gap in the probability of working in the public sector rather than the for-profit sector is attributable to these observable characteristics. On the contrary, the unexplained component of the gender gap in the probability of working in the nonprofit sector rather than in the for-profit sector is strictly positive. In other words, if men had the same individual, job and employer characteristics as women, then their probability of working in the public sector rather than in the for-profit sector would be higher than that of women, whereas female employees would still be more likely to work in the nonprofit sector.

Table 3 also reports the separate contributions from gender differences in each set of independent variables. We begin by analyzing the reasons behind the overrepresentation of women in public and nonprofit jobs compared with for-profit jobs (see columns one and two). 
We then explain why female employees are more likely than men to be employed in the nonprofit sector rather than in the public sector (see column three).

As expected, the overrepresentation of women in the public and nonprofit sectors is closely linked to an occupational segregation effect. If the distribution of occupations between these two sectors were similar, then the observed gender gap in public versus for-profit employment probability would be reduced by 5.6 percentage points, representing a decrease of $37.35 \%$. This decrease would be nearly 50 percent if we consider the observed gender gap in the probability of nonprofit versus for-profit employment. Thus, the feminization of the public and nonprofit sectors largely reflects the feminization of certain occupations. In fact, these sectors differ from the for-profit sector because of their higher concentration of femaledominated occupations, such as professors, scientific occupations, computing professionals, arts and entertainment occupations, teachers, intermediate health and social work occupations, and intermediate civil service occupations. More specifically, the feminization of the nonprofit sector is also explained by a higher proportion of clerks and service workers, whereas the feminization of the public sector results from a lower proportion of maledominated occupations, such as technicians, foremen/women and supervisors. Nevertheless, behind this occupational segregation effect, several other reasons contribute to the feminization of the public and nonprofit sectors.

The major contributor to the gender gap in the public/for-profit sector choice is the difference in family-friendly benefits offered by organizations (the opportunity to adapt working hours, child-care systems and financial payments); the sum of these three components accounted for 44.3 percent of the overall gender differences. Nevertheless, this factor explains only a small fraction of the gender gap in the nonprofit/for-profit sector choice (7.3 percent of the overall gender difference $)^{13}$. The overrepresentation of women in the public sector is linked to the generosity of the public sector in terms of financial allowances 
for child care and for caring for children with disabilities. Moreover, women are more likely than men to choose a job in the public sector because it offers more child-care possibilities in the form of day-care centers. Among the opportunities for adapting working hours to suit family constraints, the ease of having a part-time job for family reasons and the greater possibility offered by public organizations to adjust working hours at the beginning of the school year also contribute to the feminization of this sector.

In addition to their likely greater attraction to family-friendly practices, women may be expected to favor organizations with work arrangements offering a flexible work-life balance. But, the feminization of the public sector is not associated with work arrangements that offer a more flexible work-life balance. By contrast, the overrepresentation of women in the nonprofit sector results from greater offerings of part-time jobs, shorter workweeks and, to a lesser extent, a higher number of days off for reduction of working time. Taken together, these three practices account for $17.5 \%$ of the overall gender differences.

A total of $4.6 \%$ of the gender difference in the probability of working in the public sector rather than in the for-profit sector is explained by the finding that women in the public sector obtain an average hourly wage that is $7.8 \%$ higher than that offered in the for-profit sector, whereas this gain is only $2.4 \%$ for men. Although women obtain a slight supplementary wage benefit of $1.4 \%$ from joining the nonprofit sector rather than the for-profit sector, whereas men obtain a wage penalty of $3.0 \%$, this wage differential does not significantly explain the feminization of the nonprofit sector. The wage advantage that women obtain from working in the public or nonprofit sectors rather than the for-profit sector is partly explained by a lower degree of gender pay discrimination, as measured by the Oaxaca-Blinder decompositions presented in Table A1 of the appendix. In fact, the unexplained part of the wage differential between men and women is lower in the public and nonprofit sectors than in the for-profit sector. 
If public organizations provided the same amount of fringe benefits other than familyfriendly policies as that provided by for-profit organizations, then the gender difference in the probability of working in the public sector rather than in the for-profit sector would decline by 4.46 percentage points, representing a decrease of $30 \%$. Similarly, the gender difference in the probability of working in the nonprofit sector rather than in the for-profit sector would be reduced by 2.73 percentage points, a decrease of $15.2 \%$. More specifically, the overrepresentation of women in the public and nonprofit sectors stems from the reluctance of men to join these sectors because of the lack of specific savings plans and life insurance policies as well as the partial financing of mutual insurance. On the contrary, the greater offering of holiday vouchers in the public and nonprofit sectors explains the overrepresentation of women in these sectors.

The gender differences in the proxies intended to reflect the pro-social and intrinsic motivations of employees explain a small but significant share of the gender gap in employment sector choices. In particular, the weaker pecuniary motivation of women in their job choices contributes slightly to the feminization of the public and nonprofit sectors.

The third column of Table 3 shows that the main reason for the higher proportion of women in the nonprofit sector compared with the public sector is the occupational segregation effect. In fact, nearly one-quarter of the gender gap in the probability of working in the nonprofit sector rather than the public sector results from a higher concentration of femaledominated occupations in the nonprofit sector. Moreover, three family-friendly practices explain why female employees are more likely than males to be employed in the nonprofit sector rather than in the public sector: the possibility of access to holiday camps, the allowance for children with disabilities and the possibility of working from home in the event of personal constraints. Finally, this higher probability of women also results from the greater 
access to part-time jobs offered by nonprofit organizations and the lower proportion of night work. 


\section{Concluding remarks}

This paper aims to disclose the reasons for the overrepresentation of women in public and nonprofit organizations. The employee-employer matched data that are used are rich and thus allow us to consider a large scope of potential reasons. To properly assess the relative weight of these reasons for the observed gender gap in sectoral employment, we perform the nonlinear decomposition method proposed by Fairlie (2005).

The detailed results of the decomposition show that beyond the well-known occupational segregation effect, three common factors explain the overrepresentation of women in the public and nonprofit sectors, although these factors differ in terms of their relative magnitude. The first common factor is the larger number of family-friendly practices that are offered by these two sectors. However, their relative weight in the gender employment gap differs considerably. The sum of the adaptation of working hours, direct access to child-care systems and pecuniary benefits account for $44 \%$ of the gender gap in public versus for-profit employment but only $7 \%$ of the gender gap in nonprofit versus for-profit employment. The second factor results from the fact that fringe benefits that are not related to family-friendly policies are more frequently provided by the for-profit sector than by the other two sectors. In other words, the overrepresentation of women in the public and nonprofit sectors may stem from men's attraction to such fringe benefits more frequently provided by the for-profit sector. Nevertheless, it is worth noting that these benefits account for around $30 \%$ of the gender gap in public versus for-profit employment while only $15 \%$ of the gender gap in nonprofit versus for-profit employment. Finally, we find mild evidence suggesting that the overrepresentation of women in the nonprofit and public sectors may result from female employees' attaching less importance to compensation levels when selecting a job. There also exist two sector-specific factors. First, the greater access to part-time jobs and shorter 
workweeks explain the overrepresentation of women in the nonprofit sector only. Second, the feminization of the public sector results from the higher wage advantage that women obtain from working in this sector rather than the for-profit sector relative to that of men.

Altogether, these results illustrate that if both the public and nonprofit sectors attract a high percentage of female employment, public administrations and nonprofits do not primarily resort to the same pecuniary and non-pecuniary tools to recruit women. If it is conventional wisdom that nonprofit and public organizations appear to be similar because of the nature of their mission and the motivation of their workforce, then our evidence serves to question the rationale for their different sets of practices. Theoretical justification exists to contrast the compensation policies that are chosen by for-profit firms and nonprofit and governmental organizations. For example, Preston (1990) notes that the specific constraints under which nonprofit organizations work may explain the differences in the structure of compensation policy and the use of family-oriented practices compared with for-profit organizations. Furthermore, the goal of attracting workers motivated by public service motivation (PSM) explains the reluctance of public and nonprofit employers to resort to extrinsic monetary motivators, such as performance pay and pecuniary benefits. However, a theoretical framework to explain the differences in the human resources practices of public and nonprofit organizations has yet to be written. For example, do public employers have a cost advantage in providing family-friendly practices? Alternatively, to motivate women with family obligations, why would it be less costly for nonprofits to propose a shorter and more flexible workweek than to offer tools such as child-care systems that help to extend the available work time?

In comparison with previous empirical studies, this work has the advantage of providing a cardinal measure of the relative weight of workplace practices in explaining gender differences in employment. Therefore, our comparative quantification could help policy 
makers to determine how the male-female distribution between sectors will change with the legalization of a given family-friendly policy. Moreover, Themudo (2009) finds a positive relationship between women's empowerment and employment in the nonprofit sector partly because nonprofit organizations fight against discrimination and seek to advance the interests of women in society. Consequently, highlighting the reasons for the overrepresentation of women in the nonprofit sector may be useful to promote the empowerment of women.

Finally, the aggregate results from the decomposition show that if men had the same individual, job and employer characteristics as women, then their probability of working in the public sector rather than in the for-profit sector would be much higher than that of women. Hence, this result raises a new theoretical question: what unobserved factors render the public sector especially attractive for men? An extensive theoretical and empirical literature shows that regardless of gender, individuals with high levels of PSM, which represents an individual's altruistic motivation to serve the interest of organized communities, such as a nation, are more willing to choose a job in the public sector than those with lower levels of PSM. Consequently, one possible answer to this question may be found in the gender differences existing in the four constituent dimensions of public service motivation: "attraction to policy making," "commitment to the public interest," "compassion" and "selfsacrifice." In fact, several studies show that compassion is a feminine dimension of PSM, whereas males are more attracted to policy making ${ }^{14}$ than their female counterparts (see, for example, DeHart-Davis et al., 2006). Hence, the greater attraction of men to policy making appears to be better addressed by public organizations. Similarly, the finding that, all things being equal, women would still be more likely than men to work in nonprofit organizations may suggest that these organizations appear to provide the best opportunities to satisfy their higher level of demonstrated concern for others. Therefore, our results imply a more complicated pattern of sector choice than has been suggested in the theoretical literature. 
Despite the richness of the organizations' practices as depicted in our database, its crosssectional nature prevents further causal assessment. We cannot claim that the human resource policies that are chosen in each sector are the unique cause of gender-based attraction. A more complete model would specify the behavior of productive organizations. Further research based on longitudinal employer-employee matched data would be necessary to identify behavioral patterns simultaneously on both sides of the labor market. 


\section{Appendix}

Table A1. Blinder-Oaxaca decomposition of hourly wage differential between men and women within each sector

\begin{tabular}{|l|c|c|c|}
\hline & Public sector & For-profit sector & Nonprofit sector \\
\hline Explained part & $0.0570^{* * *}$ & 0.0228 & 0.0512 \\
& $(0.0197)$ & $(0.015)$ & $(0.048)$ \\
Unexplained part & $0.0912^{* * *}$ & $0.131^{* * *}$ & 0.0728 \\
& $(0.021)$ & $(0.015)$ & $(0.072)$ \\
\hline Observed differential $(\log )$ & 0.1482 & 0.1538 & 0.1240 \\
\hline
\end{tabular}

Source : Ined-Insee, Familles et Employeurs, 2004-2005.

Note: for each sector, this table presents a breakdown of the average wage difference between men and women into an explained part and an unexplained part, calculated using the following equation:

$$
\overline{\ln W_{m}}-\overline{\ln W_{f}}=\underbrace{\hat{\beta}_{f}^{\prime}\left(\bar{X}_{m}-\bar{X}_{f}\right)}_{\text {exp lained }}+\underbrace{\left(\hat{\beta}_{m}-\hat{\beta}_{f}\right)^{\prime} \bar{X}_{m}}_{\text {part }}
$$

Standard errors are presented in brackets.

*** indicate that the explained and unexplained parts of the wage differentials are significantly different from zero at 1 percent level. 


\section{Endnotes}

${ }^{1}$ CNRS is the French National Center for Scientific Research.

${ }^{2}$ INED is the French National Institute for Demographic Studies, and INSEE is the French National Statistics Institute.

${ }^{3}$ Micheaux and Monso (2007) show that mothers who are employed in the public sector have better access to day-care centers and playschools.

${ }^{4}$ The original definition of intrinsic motivation is provided by Deci (1971): "one is said to be intrinsically motivated when he receives no apparent reward except the activity itself".

${ }^{5}$ Nonprofit organizations are sorted into social cooperatives, religious nonprofits and nonreligious nonprofits.

${ }^{6}$ The legal workweek in France is 35 hours. When employees exceed this legal limit, they benefit from days off in compensation, known as reductions in work time.

${ }^{7}$ Here, we use the term "public sector" in the broadest sense (i.e., including nationalized companies).

${ }^{8}$ In these wage equations, the explained variable corresponds to the log of the net hourly wage, and the explanatory variables considered are marital status, number of children, actual work experience, job tenure, level of education and occupational group dummies.

${ }^{9}$ Until they attend secondary school, French children do not have school on Wednesdays.

${ }^{10}$ Furthermore, the marginal effect of this second proxy of intrinsic motivation on sector choices remains unchanged when the level of education is included or excluded from the model.

${ }^{11}$ The results are not presented here but are available upon request from the authors.

${ }^{12}$ It is important to note that the ordering of variables $\left(x_{1}\right.$ before $x_{2}$ or the reverse) in the decomposition influences the results because of the non-linearity of the decomposition equation. We have implemented the solution proposed by Fairlie, that is, to randomize the ordering of variables.

${ }^{13}$ Only financial assistance for child care contributes to explaining the overrepresentation of women in the nonprofit sector.

${ }^{14}$ Attraction to policy making is a public service motive that is based on the desire to satisfy personal needs while participating in the process of policy formulation. 


\section{References}

Anheier, H.K. (2005). Nonprofit Organizations: Theory, Management and Policy. New York, NY, London: Routledge.

Bem, S.L. (1974). The Measurement of Psychological Androgyny, Journal of Consulting and Clinical Psychology, 42, 155-62.

Bénabou, R. \& Tirole, J. (2006). Incentives and Prosocial Behaviour”. American Economic Review, 96(5), 1652-1678.

Bollinger, D. \& Hofstede, G. (1987). Les différences culturelles dans le management. Comment chaque pays gère-t-il ses hommes? [Cultural differences in management. How does each country manage men?]. Paris: Editions d'organisation.

Borzaga, C. \& Tortia, E. (2006). Worker Motivations, Job Satisfaction, and Loyalty in Public and Nonprofit Social Services. Nonprofit and Voluntary Sector Quarterly, 35, 225-248.

Bué, J. (2002). Temps partiel des femmes : entre 'choix' et contraintes. Premières Synthèses, $n^{\circ} 8.02$.

Croson, R. \& Gneezy, U. (2009). Gender Differences in Preferences. Journal of Economic Literature 47(2), 448-474.

Deci, E.L. (1971). Effects of Externally Mediated Rewards on Intrinsic Motivation. Journal of Personality and Social Psychology, 22(1), 113-120.

DeHart-Davis, L. Marlowe, J. \& Pandey, S.K. (2006). Gender Dimensions of Public Service Motivation. Public Administration Review, 66(6), 873-887.

Eckel, C. \& Grossman, P. (2008). Subsidizing charitable contributions: a natural field experiment comparing matching and rebate subsidies. Experimental Economics, 11, 234252. 
Ertas, N. (2012). Public Service Motivation Theory and Voluntary Organizations: Do Government Employees Volunteer More? Nonprofit and Voluntary Sector Quarterly. Advance online publication doi: 10.1177/0899764012459254.

Etienne, J-M. \& Narcy, M. (2010). Gender wage differentials in the French nonprofit and forprofit sectors: evidence from quantile regression. Annals of Economics and Statistics, n99-100, 67-90.

Fairlie, R. (2005). An extension of the Blinder-Oaxaca decomposition technique to logit and probit models. Journal of Economic and Social Measurement, 30, 305-316.

Faulk, L., Edwards, L.H., Lewis, G.B. \& McGinnis, J. (2012). An Analysis of Gender Pay Disparity in the Nonprofit Sector: An Outcome of Labor Motivation on Gendered Jobs? Nonprofit and Voluntary Sector Quarterly. Advance online publication doi: $10.1177 / 0899764012455951$.

Forbes, K.F. \& Zampelli, E.M, (2012). Volunteerism: The Influences of Social, Religious, and Human Capital. Nonprofit and Voluntary Sector Quarterly. Advance online publication doi: 10.1177/0899764012458542.

Gilligan, C. (1982). In a Different Voice : Psychological Theory and Women's Development, Harvard University Press, Cambridge.

Gregg, P. Grout, P.A. Ratcliffe A. Smith, S. \& Windmeijer, F., (2011). How important is prosocial behaviour in the delivery of public services? Journal of Public Economics, 95, 758766.

Hackman, J.R. \& Oldham, G.R. (1975). Development of the Job Diagnostic Survey. Journal of Applied Psychology, 60, 159-170.

Hoffnar, E. \& Greene, M. (1998). Gender discrimination in the public and for-profit sectors: A sample selectivity approach. Journal of Socio-Economics, 25, 105-114. 
INSEE, (2007). Femmes et Hommes. Regards sur la Parité, [Women and men: Perspectives on gender equality]. Statistique Publique et INSEE.

Lanfranchi, J. \& Narcy, M. (2006). Wages and effort in the French for-profit and nonprofit sectors: Labor donation theory revisited. Document de travail ERMES, 06-20.

Lanfranchi, J. \& Narcy, M. (2010). Shedding New Light on Intrinsic Motivation to Work: Evidence from a Discrete Choice Experiment. Kyklos: International Review for Social ciences, 63, 88-106

Leete, L. (2000). Wage Equity and Employee Motivation in Nonprofit and For-Profit Organizations, Journal of Economic behaviour and Organization, 43, 423-446.

Light, P. (2002). The content of their character: The state of the nonprofit workforce. The Nonprofit Quarterly, 9, 6-16.

Meurs, D. \& Ponthieux, S. (2006). L'écart de salaire entre les hommes et les femmes peut-il encore baisser? [Does the gender wage gap still fall?]. Économie et Statistique, $\mathrm{n}^{\circ} 398$ 399, 99-129.

Micheaux, S. \& Monso, O. (2007). Faire garder ses enfants pendant son temps de travail. Insee Première, $\mathrm{n}^{\circ} 1132,1-4$.

Mosca, M., Musella, M. \& Pastore F. (2007). Relational Goods, Monitoring and NonPecuniary Compensations in the Nonprofit Sector: the Case of the Italian Social Services. Annals of Public and Cooperative Economics, 78, 57-86.

Nielsen, H.S., Simonsen, M. \& Verner, M. (2004). Does the Gap in Family-friendly Policies Drive the Family Gap? Scandinavian Journal of Economics, 106, 721-744.

Oaxaca, R.L. \& Ransom M.R. (1994). On Discrimination and the Decomposition of Wage Differentials. Journal of Econometrics, 61(1), 5-21. 
Ponthieux, S. \& Schreiber, A. (2006). Dans les couples de salariés, la répartition du travail domestique reste très inégale. [In couples of employees, the division of domestic work is still unequal]. Données Sociales: La société française, 43-52.

Preston, A.E. (1990). Women in Non-Profit Organizations: The Best Option or the Only Option. Review of Economics and Statistics, 72, 560-568.

Tchernonog, V. (2007). Le paysage associatif français. Mesures et évolutions. Dalloz, Paris.

Themudo, N. (2009). Gender and the Nonprofit Sector. Nonprofit and Voluntary Sector Quarterly, 38(4), 663-683. 


\section{Bios}

Joseph Lanfranchi is associate professor in economics at the University Panthéon-Assas, Sorbonne Universités, Paris (LEMMA). He is also research fellow at Centre d'Études de l'Emploi (CEE). His research interests include microeconometrics and personnel economics.

Mathieu Narcy is associate professor in economics at the University of Paris-Est, Créteil, France (ERUDITE). He is also research fellow at Centre d'Études de l'Emploi (CEE). His research focuses on the differences in pro-social motivation and incentives between nonprofit, public and for-profit organizations. 
Table 1. Logit regression for sector choice

Public Nonprofit Nonprofit

vs vs vs

For-profit For-profit Public

\section{Individual characteristics}

female

$\begin{array}{ccc}-0.199 * * * & 0.011 * & 0.032 * * * \\ (0.047) & (0.007) & (0.011) \\ 0.006 * * & 0.002 * * * & 0.001 \\ (0.003) & (0.000) & (0.001) \\ -0.068 & -0.003 & -0.006 \\ (0.055) & (0.007) & (0.013)\end{array}$

number of children :

no child

Ref. Ref. Ref.

one child

$0.022-0.013 * * \quad-0.017$

$\begin{array}{lll}(0.059) \quad(0.006) & (0.011)\end{array}$

two children

$\begin{array}{lll}0.023 & -0.013 & -0.020\end{array}$

$\begin{array}{lll}(0.059) & (0.008) & (0.015)\end{array}$

three or more children

$\begin{array}{lll}0.032 & -0.005 & -0.025^{* *} \\ (0.072) & (0.009) & (0.012)\end{array}$

level of education :

general lower secondary

Ref. Ref. Ref.

vocational lower secondary

$0.188^{* *} \quad 0.019 * \quad-0.011$

$\begin{array}{lll}(0.059) \quad(0.011) & (0.014)\end{array}$

vocational or general upper secondary

$\begin{array}{lll}0.258 * * * & 0.015 & -0.007\end{array}$

$\begin{array}{lll}(0.075) & (0.014) \quad(0.015)\end{array}$

undergraduates

$0.221 * * \quad 0.015 \quad-0.005$ 


$\begin{array}{lccc} & (0.088) & (0.014) & (0.017) \\ \text { graduates and above } & 0.213^{* *} & 0.017 & -0.017 \\ & (0.090) & (0.015) & (0.017) \\ \text { Wage differential estimate }(\log ) & 0.852 * * * & 0.021 & 0.001 \\ & (0.264) & (0.021) & (0.043)\end{array}$

\section{Number and type of hours worked}

part time

$\begin{array}{lll}-0.027 & 0.025^{*} & 0.021\end{array}$

$\begin{array}{lll}(0.063) & (0.015) \quad(0.016)\end{array}$

$\log$ of monthly working hours

$\begin{array}{lll}-0.139 * & -0.020 * & -0.009\end{array}$

$\begin{array}{lll}(0.081) & (0.012) \quad(0.014)\end{array}$

no weekend work

$\begin{array}{lll}-0.008 & 0.000 & -0.012\end{array}$

$\begin{array}{lll}(0.043) & (0.006) \quad(0.010)\end{array}$

no night work

$\begin{array}{lll}-0.012 & 0.008 & 0.019 *\end{array}$

$\begin{array}{lll}(0.046) & (0.006) \quad(0.011)\end{array}$

Type of working hours:

standard working hours

Ref. Ref. Ref.

rotating shifts

$\begin{array}{lll}-0.099^{*} & 0.014 & 0.026\end{array}$

$\begin{array}{lll}(0.055) & (0.015) \quad(0.027)\end{array}$

varying hours each day or each week

$\begin{array}{lll}-0.020 & 0.003 & 0.016\end{array}$

$\begin{array}{lll}(0.041) & (0.006) \quad(0.011)\end{array}$

\section{Reduction of working time (RWT)}

the employer offers a maximum of 13 RWT days per year

$$
\begin{array}{ccc}
-0.076^{*} & -0.015^{* * *} & -0.009 \\
(0.040) & (0.006) & (0.010)
\end{array}
$$

the employer offers RWT days that should be taken

$0.008 \quad 0.006 \quad-0.010$

systematically on the same day of the week

$(0.040) \quad(0.006) \quad(0.009)$

the employer offers RWT days that can be added to ordinary

$\begin{array}{lll}-0.023 & -0.001 \quad 0.024 *\end{array}$

holidays

$(0.044) \quad(0.006) \quad(0.013)$ 


\section{Adapting working hours related to family-friendly policy}

part-time work always granted on request

family life taken into account for adjusting of part-time work

(for all employees)

family life taken into account for working hours (for all

employees)

family life taken into account for the organization of missions

and business travels (for all employees)

adjusting working hours for the start of the school year

adjusting working hours to fit in with school or day-care

centre

adjusting working hours in the event of sick children

possibility of working from home in the event of personal

constraints

\section{Child-care systems}

existence of a day-care centre or possibility of obtaining

places in one

existence of a day nursery

Possibility of access to holyday camps or resorts

\section{Fringe benefits related to family-friendly policy}

financial help for child-care

$$
\begin{array}{ccc}
0.167 * * * & 0.001 & -0.012 \\
(0.037) & (0.005) & (0.010)
\end{array}
$$

$\begin{array}{ccc}0.151 * * * & 0.007 & -0.018 * * \\ (0.050) & (0.008) & (0.009) \\ 0.038 & 0.009 & -0.006 \\ (0.079) & (0.013) & (0.013) \\ -0.150 * * * & 0.004 & 0.029 \\ (0.057) & (0.011) & (0.026) \\ 0.125 * * * & 0.002 & -0.012 \\ (0.045) & (0.007) & (0.015)\end{array}$

$\begin{array}{lll}-0.027 & 0.004 & 0.012 \\ (0.042) & (0.006) & (0.011) \\ -0.020 & 0.009 * & 0.010 \\ (0.042) & (0.006) & (0.009)\end{array}$

$0.175 * * * \quad 0.003 \quad-0.028 * * *$

$\begin{array}{lll}(0.064) \quad(0.010) & (0.009)\end{array}$

$\begin{array}{ccc}0.497 * * * & 0.034 & -0.047 * * * \\ (0.084) & (0.043) & (0.010) \\ 0.096 & -0.021 * * * & -0.045 * * * \\ (0.097) & (0.007) & (0.011) \\ 0.270 * * * & -0.013 * * & -0.058 * * * \\ (0.045) & (0.006) & (0.016)\end{array}$

$\begin{array}{ccc}0.471 * * * & 0.093 * * * & -0.025 * * \\ (0.047) & (0.035) & (0.013)\end{array}$


financial help with school costs

allowance for handicapped child

\section{Fringe benefits not related to family-friendly policy}

life insurance, benefit plans

specific savings plans

pension plans

funding of a mutual insurance plan for all employees

holiday vouchers

\section{Pro-social motivation (proxies)}

campaigning or community-interest activity

religion important or fairly important

\section{Intrinsic/extrinsic motivation (proxies)}

job criterion: "suitability in terms of taste and/or training"

job criterion: "wage, compensation"

$$
\begin{array}{ccc}
0.007 & 0.003 & -0.005 \\
(0.049) & (0.008) & (0.011) \\
0.403 * * * & 0.005 & -0.1221 * * \\
(0.052) & (0.013) & (0.023)
\end{array}
$$

$\begin{array}{lll}(0.041) & (0.009) \quad(0.009)\end{array}$

$$
\begin{array}{ccc}
-0.294 * * * & -0.012 * * & 0.091 * * * \\
(0.039) & (0.006) & (0.022)
\end{array}
$$$$
-0.426 * * * \quad-0.084 * * * \quad-0.027 * *
$$$$
\begin{array}{lll}
(0.039) & (0.013) \quad(0.012)
\end{array}
$$$$
0.045 \quad 0.003 \quad-0.039 * * *
$$$$
\begin{array}{lll}
(0.052) \quad(0.009) \quad(0.011)
\end{array}
$$$$
-0.361 * * * \quad-0.030 * * * \quad 0.033 * *
$$$$
\begin{array}{lll}
(0.036) & (0.009) \quad(0.013)
\end{array}
$$$$
0.139 * * * \quad 0.035^{* * *} \quad 0.017 * *
$$$$
\begin{array}{lll}
(0.041) & (0.009) \quad(0.009)
\end{array}
$$

$\begin{array}{lll}0.021 & 0.010 & 0.018 \\ (0.067) & (0.012) & (0.017)\end{array}$

$\begin{array}{lll}0.036 & 0.002 & 0.020 \\ (0.045) & (0.006) & (0.012)\end{array}$

$\begin{array}{lll}(0.045) & (0.006) & (0.012)\end{array}$

$\begin{array}{ccc}0.029 & 0.025^{* *} & 0.007 \\ (0.055) & (0.012) & (0.012) \\ -0.108^{* * *} & -0.009 & -0.006 \\ (0.039) & (0.006) & (0.009)\end{array}$

\section{Occupations}

Unskilled blue-collar workers 
Skilled blue-collar workers

Clerks and service workers

Intermediate occupations 3

Intermediate occupations 2

Intermediate occupations 1

White-collar 2

White-collar 1

$$
\begin{array}{lll}
-0.234 * * * & 0.019 & 0.128
\end{array}
$$

$$
\begin{array}{lll}
(0.043) & (0.026) \quad(0.104)
\end{array}
$$

$0.071 \quad 0.150^{* *} \quad 0.114^{*}$

$(0.068) \quad(0.073)$

$\begin{array}{lll}-0.212 * * * & 0.086 & 0.266\end{array}$

$(0.046) \quad(0.067)$

$\begin{array}{lll}-0.258 * * * & 0.126 & 0.633 * * *\end{array}$

$\begin{array}{lll}(0.041) & (0.082) & (0.1889)\end{array}$

$0.521 * * * \quad 0.770 * * * \quad 0.173 *$

$(0.077) \quad(0.120)$

$\begin{array}{lll}-0.221 * * * & 0.118 & 0.258 *\end{array}$

$(0.052) \quad(0.079)$

$0.504 * * * \quad 0.635 * * * \quad 0.138$

$(0.103) \quad(0.206)$

\section{Log likelihood}

$\begin{array}{lll}-508.26 & -332.45 & -313.60\end{array}$

$\mathbf{N}$

2477

1759

1206

Source : Ined-Insee, Familles et Employeurs, 2004-2005.

Note: The coefficients presented correspond to the marginal effects (calculated at the mean point). Standard errors are in brackets. Coefficient significant at the level of: $* * * 1 \%, * * 5 \%, * 10 \%$.

Intermediate occupations 1: teachers and assimilated occupations, intermediate health and social work occupations, intermediate civil service occupations; Intermediate occupations 2: intermediate corporate administrative and commercial occupations; Intermediate occupations 3: technicians, foremen/women, supervisors; White-collar 1: Professors, scientific occupations, computing, arts and entertainment occupations; White-collar 2: senior civil service, corporate administrative and commercial managers, corporate engineers and technical executives. 
Table 2. Individual, job and firm characteristics by gender

\section{Women Men}

\section{Sector}

For-profit

Public

Nonprofit

\section{Individual characteristics}

age

Not single

number of children :

no child

one child

two children

$37.58^{* *}$

three or more children

level of education :

general lower secondary

vocational lower secondary

vocational or general upper secondary

17.92

undergraduates

graduates and above

\section{Wage differentials estimates}

public - for-profit

nonprofit - for-profit

public- nonprofit

$4.4 \%$

Number and type of hours worked 
part time

$\log$ of monthly working hours

$4.93 * * *$

no weekend work

$49.70 * * *$

40.34

no night work

$62.95 * * *$

Type of working hours:

standard working hours

rotating shifts

$9.64 * * *$

varying hours each day or each week

$38.33^{* * *} *$

\section{Reduction of working time (RWT)}

the employer offers a maximum of 13 RWT days per year

$25.15 * * *$

the employer offers RWT days that should be taken systematically on

the same day of the week

the employer offers RWT days that can be added to ordinary holidays

37.50

\section{Adapting working hours related to family-friendly policy}

part-time work always granted on request

$52.71 * * *$

family life taken into account for adjusting of part-time work (for all

employees)

family life taken into account for working hours (for all employees)

$10.54 * * *$

family life taken into account for the organization of missions and business travels (for all employees)

adjusting working hours for the start of the school year

\section{Child-care systems}

existence of a day-care centre or possibility of obtaining places in one 


\section{Fringe benefits related to family-friendly policy}

financial help for child-care

financial help with school costs

allowance for handicapped child
$34.41 * * *$

$34.34 *$

$31.78 * * *$

$46.46^{* * *}$

$30.42 * * *$

24.70

$47.89 * * *$

$53.92 * * *$

holiday vouchers

\section{Pro-social motivation (proxies)}

campaigning or community-interest activity

religion important or fairly important

\section{Intrinsic/extrinsic motivation (proxies)}

Job criterion: "suitability in terms of taste and/or training"

$19.05 * * *$

$35.24 * * *$

Job criterion: "wage, compensation"

$\begin{array}{rr}8.13^{* *} & 10.55 \\ 24.25^{* * *} & 16.08\end{array}$

White-collar 2

$9.04 * * *$

Intermediate occupations 1

$15.81^{* * *}$

6.68

Intermediate occupations 2

$9.94 * * *$

Intermediate occupations 3

$3.01 * * *$

Clerks and service workers

$44.95^{* * *}$

Skilled blue-collar workers

$5.35 * * *$

Unskilled blue-collar workers
$6.25 * * *$ 
Source : Ined-Insee, Familles et Employeurs, 2004-2005.

Note: $* * *$ and $* * *$ indicate significant inequality of means at the 10,5 and 1 per cent level, respectively.

Intermediate occupations 1: teachers and assimilated occupations, intermediate health and social work occupations, intermediate civil service occupations; Intermediate occupations 2: intermediate corporate administrative and commercial occupations; Intermediate occupations 3: technicians, foremen/women, supervisors; White-collar 1: Professors, scientific occupations, computing, arts and entertainment occupations; White-collar 2: senior civil service, corporate administrative and commercial managers, corporate engineers and technical executives. 
Table 3. Decompositions of gender gaps in sector choices

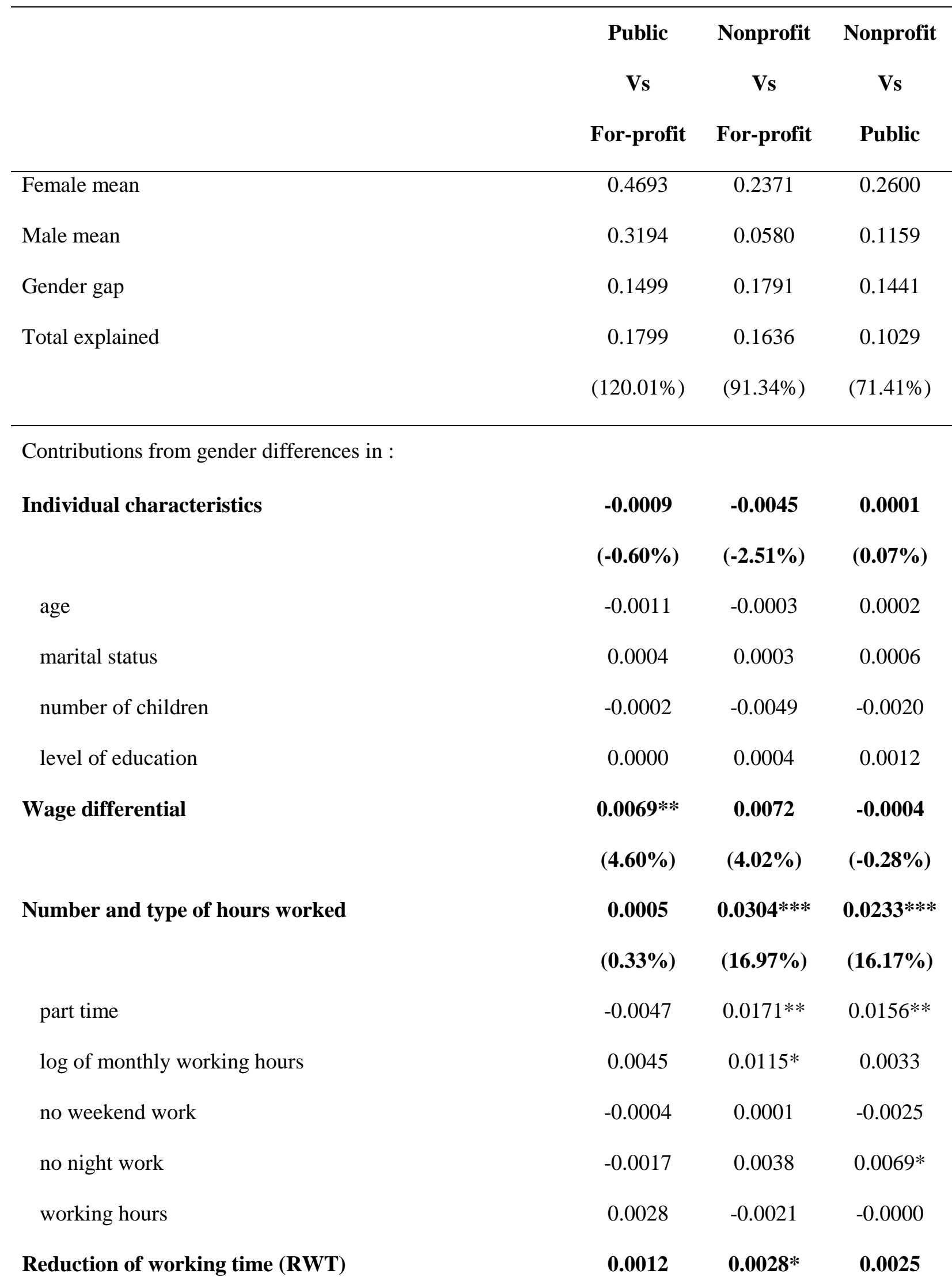




\begin{tabular}{|c|c|c|c|}
\hline & $(0.80 \%)$ & $(1.56 \%)$ & $(1.73 \%)$ \\
\hline the employer offers a maximum 13 RWT days per year & $0.0016 *$ & $0.0028 * *$ & 0.0006 \\
\hline the employer offers RWT days that should be taken & -0.0000 & -0.0000 & 0.0004 \\
\hline \multicolumn{4}{|l|}{ systematically on the same day of the week } \\
\hline the employer offers RWT days that can be added to & -0.0004 & -0.0000 & 0.0015 \\
\hline \multicolumn{4}{|l|}{ ordinary holidays } \\
\hline \multirow[t]{2}{*}{ Adapting working hours related to family-friendly policy } & $0.0107 * * *$ & $0.0043 * *$ & $0.0103 * * *$ \\
\hline & $(7.14 \%)$ & $(2.40 \%)$ & $(7.15 \%)$ \\
\hline part-time work always granted on request & $0.0055 * * *$ & 0.0005 & 0.0011 \\
\hline family life taken into account for adjusting of part-time & $0.0040 * * *$ & 0.0011 & -0.0007 \\
\hline \multicolumn{4}{|l|}{ work (for all employees) } \\
\hline family life taken into account for working hours (for all & 0.0003 & 0.0007 & -0.0006 \\
\hline \multicolumn{4}{|l|}{ employees) } \\
\hline family life taken into account for the organization of & -0.0001 & 0.0001 & 0.0026 \\
\hline \multicolumn{4}{|l|}{ missions and business travels (for all employees) } \\
\hline adjusting working hours for the start of the school year & $0.0014 * *$ & 0.0001 & 0.0016 \\
\hline adjusting working hours to fit in with school or day-care & 0.0003 & 0.0005 & 0.0004 \\
\hline \multicolumn{4}{|l|}{ centre } \\
\hline adjusting working hours in the event of sick children & -0.0001 & 0.0013 & 0.0004 \\
\hline possibility of working from home in the event of personal & -0.0006 & -0.0000 & $0.0059 * * *$ \\
\hline \multicolumn{4}{|l|}{ constraints } \\
\hline \multirow[t]{2}{*}{ Child-care systems } & $0.0073 * * *$ & 0.0013 & $0.0178 * * *$ \\
\hline & $(4.87 \%)$ & $(0.72 \%)$ & $(\mathbf{1 2 . 3 5 \%})$ \\
\hline existence of a day-care center or possibility of obtaining & $0.0057 * * *$ & 0.0003 & $-0.0028 * *$ \\
\hline \multicolumn{4}{|l|}{ places in one } \\
\hline existence of a day nursery & 0.0001 & 0.0000 & $0.0034 * *$ \\
\hline Possibility of access to holyday camps or resorts & 0.0015 & 0.0010 & $0.0172 * * *$ \\
\hline
\end{tabular}




\begin{tabular}{|c|c|c|c|}
\hline Fringe benefits related to family-friendly policy & $\begin{array}{l}0.0485 * * * \\
(32.35 \%)\end{array}$ & $\begin{array}{l}0.0076 * * \\
(4.13 \%)\end{array}$ & $\begin{array}{c}0.0092 * * * \\
(6.38 \%)\end{array}$ \\
\hline financial help for child-care & $0.0275 * * *$ & $0.0078 * * *$ & 0.0006 \\
\hline financial help with school costs & 0.0002 & -0.0002 & -0.0000 \\
\hline allowance for handicapped child & $0.0202 * * *$ & 0.0000 & $0.0086^{* * *}$ \\
\hline Fringe benefits not related to family-friendly policy & $\begin{array}{l}0.0446 * * * \\
(29.75 \%)\end{array}$ & $\begin{array}{l}0.0273 * * * \\
(15.24 \%)\end{array}$ & $\begin{array}{c}0.0030 \\
(2.08 \%)\end{array}$ \\
\hline life insurance. benefit plans & $0.0089 * * *$ & 0.0015 & -0.0034 \\
\hline specific savings plans & $0.0114 * * *$ & $0.0118 * *$ & 0.0038 \\
\hline pension plans & 0.0004 & -0.0004 & 0.0029 \\
\hline funding of a mutual insurance plan for all employees & $0.0189 * * *$ & $0.0087 * * *$ & -0.0003 \\
\hline holiday vouchers & $0.0050 * *$ & $0.0057 * *$ & -0.0001 \\
\hline Pro-social and intrinsic/extrinsic motivations(proxies) & $\begin{array}{c}0.0051 * * * \\
(3.40 \%)\end{array}$ & $\begin{array}{l}0.0055 * \\
(2.79 \%)\end{array}$ & $\begin{array}{c}0.0029 \\
(2.01 \%)\end{array}$ \\
\hline campaigning or community-interest activity & -0.0002 & -0.0007 & -0.0008 \\
\hline religion important or fairly important & 0.0007 & 0.0004 & 0.0012 \\
\hline job criterion: "suitability in terms of taste and/or training" & 0.0005 & 0.0018 & 0.0007 \\
\hline job criterion: "wage, compensation" & $0.0041 * *$ & $0.0040 *$ & 0.0018 \\
\hline Occupations & $\begin{array}{l}0.0559 * * * \\
(37.29 \%)\end{array}$ & $\begin{array}{c}0.0816 * * * \\
(45.56 \%)\end{array}$ & $\begin{array}{l}0.0345 * * * \\
(23.94 \%)\end{array}$ \\
\hline Sample size & 2477 & 1759 & 1206 \\
\hline Number of women & 1140 & 793 & 723 \\
\hline Number of men & 1337 & 966 & 483 \\
\hline
\end{tabular}

